\title{
Evaluation of Promalin to promote growth of young mangosteen seedlings ${ }^{1,2}$
}

\author{
Ricardo Goenaga ${ }^{3}$ \\ J. Agric. Univ. P.R. 94(3-4):105-109 (2010)
}

\begin{abstract}
A major impediment to the development of a mangosteen (Garcinia mangostana $L$.) industry is the long pre-bearing stage that seedlings require to produce fruits. A field study was conducted to determine the effect of Promalin on the growth of mangosteen seedlings. Year-old seedlings were transplanted to the field in Santa Isabel, Puerto Rico. Four applications of Promalin were used as a foliar spray at concentrations of $0,25,50,75,100$ and 125 $\mathrm{mg} / \mathrm{L}$ beginning when seedlings were approximately 2.5 years old, and then every 10 to 15 weeks over a period of almost one year. Final measurements were made 10 weeks after the final application, and 353 days after treatment initiation, when seedlings were 3.5 years old. No significant differences were observed in plant height, stem diameter, or number of branches and leaves.
\end{abstract}

Key words: mangosteen, growth regulator, BA, GA

\section{RESUMEN \\ Evaluación de Promalina para promover el crecimiento en plántulas de mangostín}

La producción comercial de mangostín es limitada debido al extenso periodo juvenil que requiere el árbol para fructificar. Se estableció un experimento de campo para determinar el efecto de la Promalina en el crecimiento de plántulas de mangostín. Plántulas de alrededor de un año de edad fueron trasplantadas al campo en Santa Isabel, Puerto Rico. La Promalina se aplicó foliarmente a concentraciones de $0,25,50,75,100$ y $125 \mathrm{mg} / \mathrm{L}$ comenzando cuando las plántulas tenían 2.5 años de edad y luego cada 10 a 15 semanas por un periodo de casi un año. Las mediciones finales se realizaron 10 semanas después de la última aplicación de Promalina y 353 días después de iniciados los tratamientos, cuando las plántulas tenían 3.5 años de edad. No se observaron diferencias significativas en la altura de las plántulas, diámetro del tallo, ni en el número de hojas y número de ramas y hojas.

Palabras clave: mangostín, regulador de crecimiento, BA, GA

${ }^{1}$ Manuscript submitted to Editorial Board 23 June 2009.

${ }^{2}$ Appreciation is expressed to Mr. Venancio Marti and Dr. Yair Aron for allowing the use of land at Martex Farms, Inc., to conduct this experiment, and to Mr. Angel Marrero for assistance in data collection. Mention of trade names or commercial products in this publication is solely for the purpose of providing specific information and does not imply recommendation or endorsement by the U.S. Department of Agriculture.

${ }^{3}$ USDA, ARS, Tropical Agriculture Research Station, Mayagüez, Puerto Rico 00680. E-mail: Ricardo.Goenaga@ars.usda.gov. 


\section{INTRODUCTION}

Mangosteen (Garcinia mangostana L.) is a tropical fruit of attractive shape and color with excellent flavor. It has great economic potential, has few pests and is often referred to as "Queen of Fruits" or "the finest fruit of the world" (Morton, 1987; Karp, 2008). The species belongs to the Clusiaceae family and is believed to be a hybrid between $G$. hombroniana and G. malaccensis (Ramage et al., 2004; Yapwattanaphun et al., 2004). The tree is strictly tropical in climate and soil requirements and thrives in well-drained clayey soils with well-distributed rainfall throughout the year (Yaacob and Tindall, 1995).

There are no known commercial clones of mangosteen. Propagation is by seeds that are recalcitrant (Doijode, 2001) and formed from nucellar tissues, which produce apomictic seedlings that are identical to the parent tree (Rao and Ramatha-Rao, 1998; Tinggal, 1992). The yield and fruit size of mangosteen will vary with the age of the bearing tree. An expected yield from the first crop is 200 to 300 fruits per tree. The yield steadily increases up to the 30th year of bearing, when harvests of 1,000 to 2,000 fruits per tree are expected (Morton, 1987; Yaacob and Tindall, 1995).

A major impediment to the development of a mangosteen industry is the long pre-bearing stage (eight to 15 years) that seedlings require to produce fruits (Wiebel et al., 1992). The author has attempted, with mixed results, to enhance mangosteen growth by grafting it onto closely related species, such as Garcinia dulcis, G. venulosa, and G. spicata. It has been demonstrated that seedlings grown in the nursery under $50 \%$ shade and supplied with $9 \mathrm{~g}$ of a 15-11-13 $\left(\mathrm{N}-\mathrm{P}_{2} \mathrm{O}_{5}-\mathrm{K}_{2} \mathrm{O}\right)$ fertilizer accumulated significantly more dry matter, had thicker stems, grew taller, and developed a larger leaf area (Goenaga and Rivera, 2005). However, after field transplanting, seedling growth remained very slow.

Promalin, a commercial formulation containing gibberelins 4 and 7 plus the cytokinin 6-Benzyladenine, is reported to stimulate cell division and expansion; hence it is recommended for promoting development of lateral branches in young apple trees and for increasing fruit size in the apple crop (Valent BiosSciences, 2009). Promalin also increases lateral bud break and shoot growth of pear and sweet cherry trees (Valent BiosSciences, 2009). Studies by Veinbrants and Miller (1981) showed that Promalin increased total shoot length, number of spurs and number of lateral shoots when applied to young cherry (Solanum pseudocapsicum) trees. This paper presents results of a study directed toward enhancing growth of mangosteen seedlings by using Promalin. 


\section{MATERIALS AND METHODS}

An experiment was established at Martex Farms, Santa Isabel, Puerto Rico. Average monthly maximum, minimum, and mean temperatures were $33.4^{\circ} \mathrm{C}, 19.5^{\circ} \mathrm{C}$, and $26.2^{\circ} \mathrm{C}$, respectively. The soil is a fine loamy, mixed isohyperthermic Cumulic Haplustoll with the following chemical characteristics: $\mathrm{pH} 7.9$; organic carbon, $0.98 \% ; \mathrm{P}, 135 \mu \mathrm{g} / \mathrm{g} ; \mathrm{K}, 154$ $\mu \mathrm{g} / \mathrm{g} ; \mathrm{Ca}, 5468 \mu \mathrm{g} / \mathrm{g} ; \mathrm{Mg}, 625 \mu \mathrm{g} / \mathrm{g}$.

One-year-old seedlings were transplanted to the field 5 November 2003 and were arranged in a randomized complete-block design with five replications. Average height, stem diameter at $6 \mathrm{~cm}$ from soil, and number of leaves of seedlings at transplanting was $12.5 \mathrm{~cm}, 4.2 \mathrm{~mm}$ and 10.1 leaves, respectively. Within a replication, plots contained two trees per treatment spaced $6.1 \mathrm{~m}$ apart and $6.1 \mathrm{~m}$ between adjacent rows in a triangular array. Treatments consisted of spraying foliage of seedlings with Promalin [N-(phenlymethyl)- $1 \mathrm{H}$-purine 6-amine and $\left.\mathrm{GA}_{4}+\mathrm{GA}_{7}\right]$ at rates of $0,25,50,75,100,125 \mathrm{mg} / \mathrm{L}$ until runoff. Treatment solutions were brought to a $\mathrm{pH}$ of 7.0 by using $1.0 \mathrm{~N} \mathrm{KOH}$ for best activity. Promalin was applied 30 June 2005; 15 September 2005; 10 January 2006; and 5 April 2006 at dusk to prevent quick drying. Two rows of Grand Naine banana plants were planted between the mangosteen rows to provide necessary shade to mangosteen plants (Goenaga and Rivera, 2005). Banana plants were spaced $1.2 \mathrm{~m}$ apart with $2.4 \mathrm{~m}$ between rows. The experiment was surrounded by two guard rows of Grand Naine banana. Irrigation based on tensiometer readings was provided through drip irrigation with two $8 \mathrm{~L} / \mathrm{h}$ emitters per plant spaced $61 \mathrm{~cm}$ apart. Fertilization was provided every three months by using a 15-5-20-3 (N- $\left.\mathrm{P}_{2} \mathrm{O}_{5}-\mathrm{K}_{2} \mathrm{O}-\mathrm{MgO}\right)$ commercial mixture at a rate of $227 \mathrm{~g} /$ tree. Herbicide for weed control was applied as necessary. Measurements of seedling height, stem diameter at $6 \mathrm{~cm}$ from soil, and number of leaves and branches were made the same day treatments were applied, except for the last sampling measurements, which were taken 19 June 2006. Analysis of variance was carried out by using the ANOVA procedure of SAS (release 9.0 for Windows; SAS Institute, Cary, NC).

\section{RESULTS AND DISCUSSION}

There were no significant differences in plant height, stem diameter, number of branches, nor number of leaves among Promalin treatments (data not shown). From treatment initiation until the end of the experimental period ( 353 days), plant height across all Promalin treatments increased by only $4.5 \mathrm{~cm}$, from $12.5 \mathrm{~cm}$ to $17 \mathrm{~cm}$. During the same period, average stem diameter increased from $4.4 \mathrm{~mm}$ to $5.2 \mathrm{~mm}$. 
Similarly, the number of branches increased from 0.10 to 0.32 , and the number of leaves from 9.9 to 11.3 during this period. The slight increase in growth was then the result of seedlings increasing in age. The fact that seedling growth was minimal, in almost a year after being field-transplanted, reflects not only that Promalin at the concentrations used in this study was ineffective in promoting growth, but also confirms the slow growth rate of mangosteen during its juvenile stage.

Studies with kale (Brassica oleracea var. Acephala) have shown that Promalin at $25,50,75 \mathrm{mg} / \mathrm{L}$ significantly increased total leaf area, plant height, leaf number and plant dry matter (Emongor et al., 2004). Similarly, as the concentration of Promalin was increased from 0 to 1,200 $\mathrm{mg} / \mathrm{L}$, dry matter and plant height of Euphorbia lathyris increased significantly (Preece, 1990). In contrast, shoot growth of apple cv. Tsugaru was not affected by spraying Promalin at $18 \mathrm{mg} / \mathrm{L}$ (Youn et al., 2004), but Promalin promoted bud sprouting and the production of trees with compact foliage when sprayed at $1,500 \mathrm{mg} / \mathrm{L}$ on apple trees cv. Catarina (Rossi et al., 2004). This study demonstrates that growth of mangosteen seedlings cannot be stimulated at Promalin concentrations ranging from 0 to $125 \mathrm{mg} / \mathrm{L}$. Studies are being initiated to determine whether seedlings respond differently at higher Promalin concentrations.

\section{LITERATURE CITED}

Doijode, S. D., 2001. Seed Storage of Horticultural Crops. Food Products Press, Binghamton, NY. 339 pp.

Emongor, V., F. Pule-Meulenberg and O. Pholes, 2004. Effect of Promalin on growth and development of kale (Brassica oleracea L. var. Acephala DC). Journal of Agronomy 3:208-214.

Goenaga, R. and E. Rivera, 2005. Growth and nutrient uptake of mangosteen grown under shade levels. J. Agric. Univ. P.R. 89:149-158.

Karp, D., 2008. Forbidden fruit? Not the mangosteen. Fruit Gardener 40:18-22.

Morton, J. F., 1987. Fruits of the warm climates. Media Incorporated, Greensboro, NC. $506 \mathrm{pp}$.

Preece, J. E., 1990. Growth stimulation of Euphorbia lathyris L. by $\mathrm{GA}_{4+7}$ and BA. J. Plant Growth Regul. 9:85-88.

Ramage, C. M., L. Sando, C. P. Peace and B. J. Carroll, 2004. Genetic diversity revealed in the apomictic fruit species Garcinia mangostana L. (mangosteen). Euphytica 136:1-10.

Rao, A. N. and V. Ramatha-Rao, 1998. Genetic resources and breeding patterns of five humid tropical fruit tree species. In: R.K. Aurora and Vramanatha-Rao (Eds.). Tropical Fruits in Asia: Diversity, Maintenance, Conservation and use. Proceedings of the IPGRI-ICAR-UTFANET Regional Training Course on the Conservation and Use of Germplasm of Tropical Fruits in Asia. Indian Institute of Horticultural Research, 18-31 May, 1997, Bangalore, India, pp. 54-69.

Rossi, A. D., L. Rufato, C. L. Giacobbo, F. R. C. Gomez and J. C. Fachinello, 2004. Use of Promalin(B) on one-year old trees of the apple cv. Catarina. Acta Horiculturae 636:145-149. 
Tinggal, S., 1992. Brunei Darussalam Fruits in Colour. Universiti Brunei Darassalam, Brunei Darussalam, $148 \mathrm{pp}$.

Valent Biosciences Corp, 2009. Promalin on apples. http://www.valentbiosciences.com/ learning_center/learning_center.asp?lc_section=promalin\&flash=promalin. Last verified: 25 April 2009.

Veinbrants, N. and P. Miller, 1981. Promalin promotes lateral short development of young cherry trees. Aust. J. Exp. Agric. Anim. Husb. 21:618-622.

Wiebel, J., W. J. S. Downton and E. K. Chacko, 1992. Le mangous tanier (Garcinia mangostana L.) une culture potentialle pour l'Australie septentrionable tropicale. Fruits 46:685-688.

Yaacob, O. and H. D. Tindall, 1995. Mangosteen cultivation. FAO Plant Production and Protection paper 129, Food and Agriculture Organization of the United Nations, Rome, Italy, pp. 28-30.

Yapwattanaphun, C., S. Subhadrabanhu, C. Honsho and K. Yonemori, 2004. Phylogenetic relationship of mangosteen (Garcinia mangostana) and several wild relatives (Garcinia spp.) revealed by ITS sequence data. J. Amer. Soc. Hort. Sci. 129:368-373.

Youn, C. K., S. K. Kim, S. C. Lim, Y. H. Kim, T. Yoon and T. S. Kim, 2004. Effects of Promalin and salicylic acid application on tree growth and fruit quality of 'Tsugaru' apples. Acta Horticulturae 653:151-154. 
